\title{
Using remote-sensing data to determine equilibrium-line altitude and mass-balance time series: validation on three French glaciers, 1994-2002
}

\author{
Antoine RABATEL, ${ }^{1,2}$ Jean-Pierre DEDIEU, ${ }^{1}$ Christian VINCENT ${ }^{1}$ \\ ${ }^{1}$ Laboratoire de Glaciologie et Géophysique de l'Environnement (CNRS-UJF), 54 rue Molière, BP 96, \\ 38402 Saint-Martin-d'Hères Cedex, France \\ E-mail: rabatel@lgge.obs.ujf-grenoble.fr \\ ${ }^{2}$ Institut de Recherche pour le Développement, UR Great Ice, Laboratoire de Glaciologie et Géophysique \\ de I'Environnement, 54 rue Molière, 38402 Saint-Martin-d'Hères Cedex, France
}

\begin{abstract}
Alpine glaciers are very sensitive to climate fluctuations, and their mass balance can be used as an indicator of regional-scale climate change. Here, we present a method to calculate glacier mass balance using remote-sensing data. Snowline measurements from remotely sensed images recorded at the end of the hydrological year provide an effective proxy of the equilibrium line. Mass balance can be deduced from the equilibrium-line altitude (ELA) variations. Three well-documented glaciers in the French Alps, where the mass balance is measured at ground level with a stake network, were selected to assess the accuracy of the method over the 1994-2002 period (eight mass-balance cycles). Results obtained by ground measurements and remote sensing are compared and show excellent correlation $\left(r^{2}>0.89\right)$, both for the ELA and for the mass balance, indicating that the remote-sensing method can be applied to glaciers where no ground data exist, on the scale of a mountain range or a given climatic area. The main differences can be attributed to discrepancies between the dates of image acquisition and field measurements. Cloud cover and recent snowfalls constitute the main restrictions of the image-based method.
\end{abstract}

\section{INTRODUCTION}

It is now widely agreed that glaciers constitute a very good indicator of climate variations (Oerlemans and others, 1998; Houghton and others, 2001; Vincent, 2002). Mass balance is directly dependent on climatic variables governing accumulation and ablation processes (Martin, 1974; Vincent and Vallon, 1997; Braithwaite and Zhang, 1999; Oerlemans and Reichert, 2000; Kaser, 2001). Thus, measurements of glacier mass balance and an understanding of its relationship with climatic variables can help improve knowledge of recent and past climate fluctuations (Oerlemans and Hoogendoorn, 1989; Vallon and others, 1998; Vincent and others, 2004). However, direct mass-balance measurements on the ground remain sparse due to the major logistical support required, and time series exceeding several decades are rare. In this context, many researchers have attempted to use information provided by remote sensing, based on the extensive image archives available for the past 30 years, to create databases and glaciological inventories (GLIMS (Global Land Ice Measurements from Space) program: Raup and others, 2000). Since the 1970s, attempts have been made to apply remote sensing to glaciological surveys (Meier, 1979). Østrem (1975) and Braithwaite (1984) presented the first snowline altitude measurements using remotely sensed data and compared them to glacier mass balances without attempting their reconstruction. Since the 1990s, many studies have tested and discussed the different possibilities offered by optical or radar remote sensing (measurement of glacier surface areas, displacements and volume variations) (Dedieu and Reynaud, 1990; Massom, 1995; Adam and others, 1997; Bindschadler, 1998; Hubbard and others, 2000; König and others, 2001; Kääb and others, 2002; Rabatel and others,
2002; De Ruyter de Wildt and Oerlemans, 2003; Berthier and others, 2004; Paul and others, 2004).

The equilibrium line divides the accumulation zone (where the mass balance is positive) from the ablation zone (where the mass balance is negative). Its fluctuation in terms of altitude results in a change in the proportion of each of these areas with respect to the whole glacier and therefore a variation of the glacier mass balance. Thus the equilibriumline altitude (ELA) is well correlated with and provides a very good indicator of the glacier mass balance (Braithwaite, 1984; Kuhn, 1989; Paterson, 1994; Leonard and Fountain, 2003).

In the present paper, we use the late-summer position of the snowline, which is easy to discern in satellite imagery, to infer the location of the equilibrium line, from which we estimate glacier mass balance. At this period, i.e. the end of the ablation season (and therefore of the hydrological year), the snowline can be associated with the equilibrium line on mid-latitude glaciers (Lliboutry, 1965). The method was applied to three glaciers in the French Alps where field measurements can be used to check results.

\section{DATA}

Three glaciers included in a French glacier monitoring program (Laboratoire de Glaciologie et Géophysique de I'Environnement (LGGE)-Observatoire des Sciences de I'Univers de Grenoble (OSUG)) were selected for this study: Glacier d'Argentière in the Mont Blanc range, Glacier de Gébroulaz in the Vanoise range and Glacier de Saint-Sorlin in the Grandes Rousses range of the French Alps (Fig. 1; Table 1). On these glaciers, annual mass balance was measured using a stake network covering the whole 


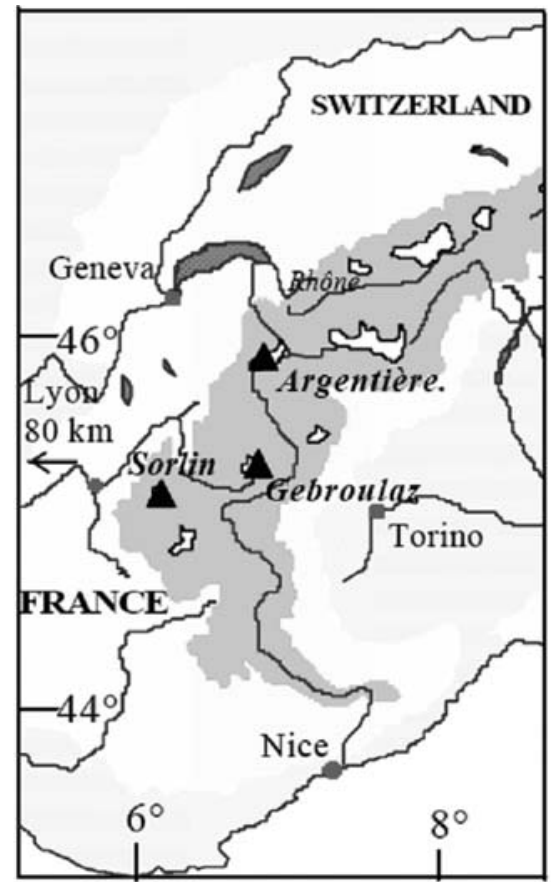

Fig. 1. Location map. Triangles represent the three French glaciers considered in this study.

ablation zone since 1957, 1975 and 1993 for Saint-Sorlin, Argentière and Gébroulaz glaciers respectively. Since 1994, systematic winter (May) and summer (September) massbalance measurements have been carried out on these glaciers. In the accumulation zone, cores are drilled to measure winter mass balance from snow layering and density measurements. Stakes inserted in the boreholes allow measurement of the remaining winter snow at the end of summer, and determination of summer mass balance. In the ablation zone, winter mass balance is measured by drilling and measuring the snow thickness above the ice. At the end of summer, annual mass balance is determined from stakes inserted in ice the previous summer. The summer mass balance is the difference between these two balance terms. Thus specific glacier-wide mass-balance variations are obtained from these field measurements. Moreover,

Table 1. Topographical characteristics of the three French glaciers

\begin{tabular}{|c|c|c|c|}
\hline & $\begin{array}{c}\text { Glacier } \\
\text { d'Argentière }\end{array}$ & $\begin{array}{c}\text { Glacier } \\
\text { de Gébroulaz }\end{array}$ & $\begin{array}{c}\text { Glacier } \\
\text { de Saint-Sorlin }\end{array}$ \\
\hline Location & $\begin{array}{c}45^{\circ} 55^{\prime} \mathrm{N} \\
6^{\circ} 57^{\prime} \mathrm{E}\end{array}$ & $\begin{array}{c}45^{\circ} 19^{\prime} \mathrm{N} \\
6^{\circ} 40^{\prime} \mathrm{E}\end{array}$ & $\begin{array}{l}45^{\circ} 10^{\prime} \mathrm{N} \\
6^{\circ} 10^{\prime} \mathrm{E}\end{array}$ \\
\hline Surface area* $\left(\mathrm{km}^{2}\right)$ & 19 & 3 & 3 \\
\hline Max. elevation (ma.s.l.) & 3600 & 3500 & 3400 \\
\hline Min. elevation (ma.s.l.) & 1600 & 2600 & 2700 \\
\hline Length (km) & 10 & 4 & 2.5 \\
\hline Exposure & North-south & North & Northeast \\
\hline $\begin{array}{l}\text { First mass-balance } \\
\text { survey }\end{array}$ & 1975 & 1993 & 1957 \\
\hline $\begin{array}{l}\text { Number of } \\
\text { measurement sites }\end{array}$ & 35 & 25 & 28 \\
\hline
\end{tabular}

*This area is slightly different from those reported in the World Glacier Monitoring Service report, which omits tributary glaciers that have split from the main glacier due to general retreat.

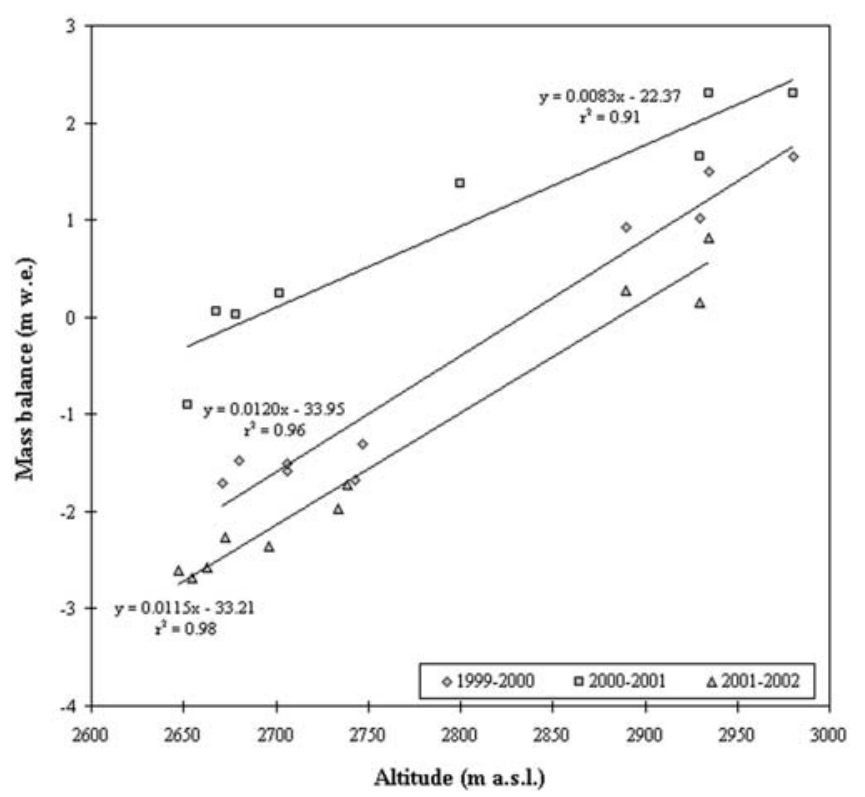

Fig. 2. Observed mass balance vs altitude close to the equilibriumline zone: example for Glacier d'Argentière, 1999-2002 (all observations were selected along the same longitudinal transect).

photogrammetric measurements have been performed using aerial photographs from 1949, 1970, 1980, 1994 and 1998 (Glacier d'Argentière), from 1953, 1967, 1986 and 1998 (Glacier de Gébroulaz) and from 1952, 1971, 1984, 1986, 1989 and 1998 (Glacier de Saint-Sorlin) to obtain the total cumulative mass balance of these glaciers. These data have been used to constrain mass-balance data obtained from the field measurements. The results have been analyzed and reported in previous studies (Vincent and others, 2000; Vincent 2002).

For each hydrological year over the 1994-2002 period, several stakes were selected on both sides of the equilibrium line, along a central axis on each glacier. The linear regression of mass balance with stake altitude was used to calculate the ELA for each year and determine the yearly glacier mass-balance gradient $\partial b / \partial z$ across the equilibrium line. An example for Glacier $d^{\prime}$ Argentière is presented in Figure 2 .

The satellite data used in this study come from several optical sensors: the Landsat Thematic Mapper, Système Probatoire pour I'Observation de la Terre (SPOT) 1-4 and the Advanced Spaceborne Thermal Emission and Reflection Radiometer (ASTER). Images were chosen depending on the quality of the archives available: recording date, absence of cloud cover, absence of recent snow cover, and pixel size. The image recording date must correspond to the end of the ablation season, i.e. late September to early October (Table 2). Figure 3 shows an example of image data used in the equilibrium-line assessment.

\section{METHOD}

Field measurements on each of the three glaciers show a good correlation between the ELA and the glacier-wide mass balance (Fig. 4). This has been shown in several studies (e.g. Braithwaite, 1984; Kuhn, 1989). We propose to use the snowline obtained from the images to infer the ELA from which we reconstruct glacier mass-balance variations. 


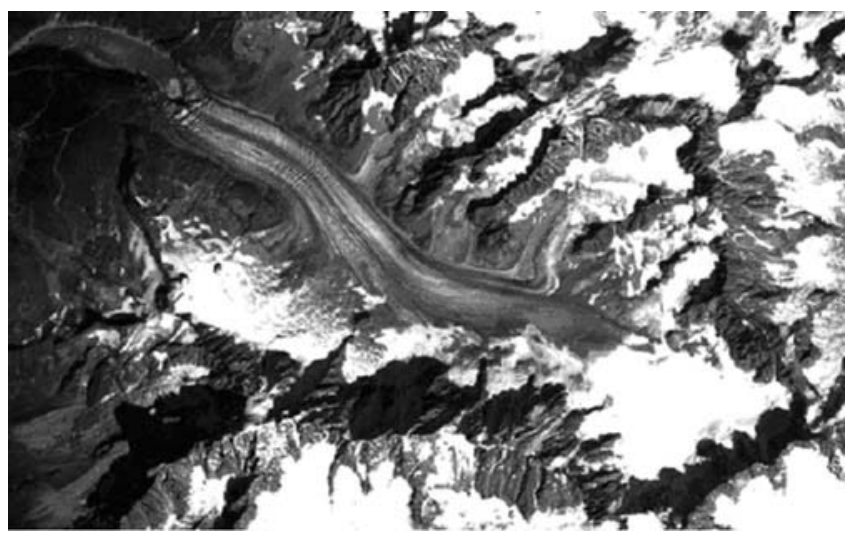

Fig. 3. Glacier $d^{\prime}$ Argentière $\left(45^{\circ} 55^{\prime} \mathrm{N}, 6^{\circ} 57^{\prime} \mathrm{E}\right)$. SPOT image from 26 August 2000, P/R 051-257, pixel size $10 \mathrm{~m}$.

First, all images were geometrically and radiometrically corrected using a digital elevation model (DEM) grid of $10 \mathrm{~m}$. To facilitate locating the snowline, shadows were reduced by enhancing the brightness of shaded areas in comparison with lighted areas, and the contrast between snow and ice was amplified. After image correction, the snowline was located and its average altitude computed using the DEM. Considering that the snowline is representative of the glacier equilibrium line when measured at the end of the hydrological year (Lliboutry, 1965; Braithwaite, 1984), we henceforth use the term ELA.

The annual average ELA was calculated on the central part of the glaciers to avoid border effects on the glacier banks (shadows from surrounding slopes, additional snow input by avalanches, over-accumulation due to wind) which could generate equilibrium-line position dependence on local conditions. With the ELA for each year determined by remote sensing, the mass-balance series can be reconstructed in two steps. First, we calculate for each year, $i$, the variation between $\mathrm{ELA}_{i}$ and an ELA representative of a steady state of the glacier, $\mathrm{ELA}_{\text {eq. }}$ ELA $\mathrm{Eq}_{\mathrm{eq}}$ represents the mean altitude that the equilibrium line would have had over the whole period if the glacier had been balanced (mass balance $=0$ ), and is obtained by:

$$
\mathrm{ELA}_{\text {eq }}=\frac{1}{n} \sum_{1}^{n}\left(\mathrm{ELA}_{i}\right)+\frac{\bar{B}}{\frac{\partial b}{\partial z}},
$$

where $\bar{B}$ is the mean glacier-wide mass balance over the period under consideration, computed from field measurements here but which can also be determined using

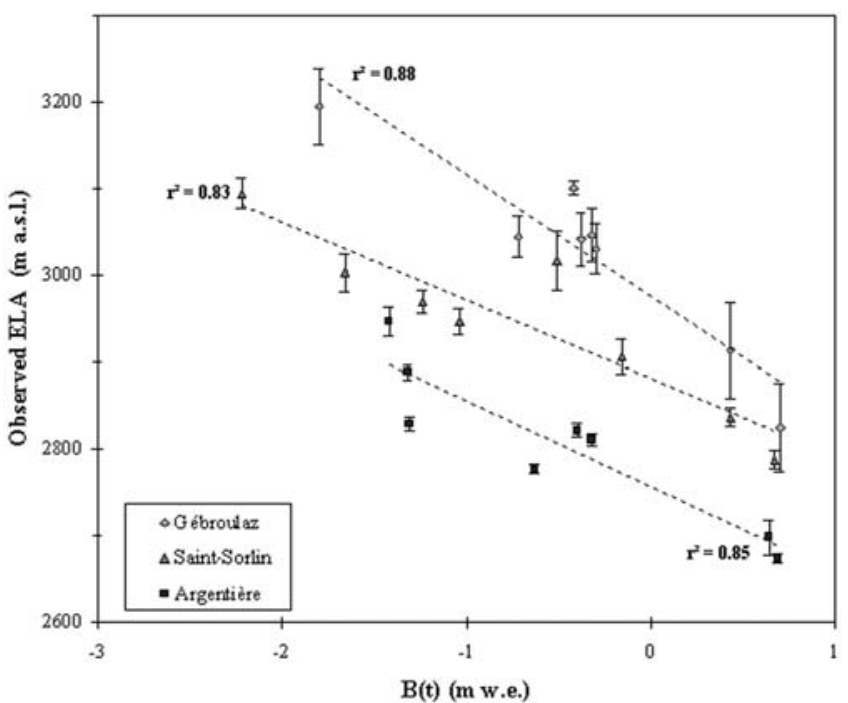

Fig. 4. ELA observed from field measurements vs glacier-wide mass balance (1994-2002). The uncertainty bars represent the confidence interval on the observed ELA obtained from the linear regression of the mass balance with stake altitude.

photogrammetry (see section 4.5), and $\partial b / \partial z$ is the massbalance gradient across the equilibrium line, fixed at $0.78 \mathrm{~m}(100 \mathrm{~m})^{-1}$ (see further below and section 4.4).

We multiply this variation of the ELA by the mass-balance gradient close to the ELA chosen for the period. The mass balance $b(t)$ computed from remote-sensing data can then be expressed as:

$$
b(t)=\left(\mathrm{ELA}_{\mathrm{eq}}-\mathrm{ELA}_{i}\right) \frac{\partial b}{\partial z} .
$$

To obtain the mass balance from the ELA variation, the massbalance gradient across the ELA, $\partial b / \partial z$, must be known. This gradient varies according to the altitude and local parameters. Mean values for the Alps are given by several authors (Lliboutry, 1965; Reynaud and others, 1986). For this study, the gradient was calculated on each glacier for each year with the measurements made on the selected stakes (Fig. 5). However, to reconstruct the mass balance over the 1994-2002 period, we used an average gradient of $0.78 \mathrm{~m}$ w.e. $(100 \mathrm{~m})^{-1}$ for all glaciers.

To validate our method, we proceeded in three steps. First, ELAs computed from remotely sensed data were compared with ELAs observed from field measurements. Next we calculated the mass balances from the remotely

\begin{tabular}{|c|c|c|c|c|c|c|c|c|c|}
\hline & \multicolumn{3}{|c|}{ Argentière } & \multicolumn{3}{|c|}{ Gébroulaz } & \multicolumn{3}{|c|}{ Saint-Sorlin } \\
\hline & Satellite/pixel & Path/row & Date & Satellite/pixel & Path/row & Date & Satellite/pixel & Path/row & Date \\
\hline 1995 & Landsat-5/30m & $196 / 028$ & 2 Sept 1995 & SPOT-2/20 m & $051 / 259$ & 31 Aug 1995 & SPOT-2/20 m & $051 / 259$ & 31 Aug 1995 \\
\hline 1996 & Landsat-5/30m & $195 / 028$ & 31 Aug 1996 & SPOT-3/20 m & $052 / 259$ & 31 July 1996 & SPOT-2/20 m & $052 / 258$ & 17 Sept 1996 \\
\hline 1997 & SPOT-1/20 m & $051 / 257$ & 25 Sept 1997 & SPOT-1/20 m & $051 / 259$ & 30 Sept 1997 & SPOT-1/20 m & $051 / 259$ & 30 Sept 1997 \\
\hline 1998 & SPOT-4/20 m & $052 / 257$ & 30 Sept 1998 & SPOT-4/20 m & $052 / 259$ & 30 Aug 1998 & SPOT-4/20 m & $052 / 259$ & 30 Aug 1998 \\
\hline 1999 & SPOT-1/20 m & $052 / 257$ & 31 Aug 1999 & SPOT-2/20 m & $051 / 259$ & 10 Sept 1999 & SPOT-4/20 m & $050 / 259$ & 9 Sept 1999 \\
\hline 2000 & SPOT-1/10 m & $051 / 257$ & 26 Aug 2000 & SPOT-2/20 m & $051 / 259$ & 15 Sept 2000 & SPOT-1/20 m & $050 / 259$ & 15 Sept 2000 \\
\hline 2001 & SPOT-1/20 m & $051 / 257$ & 22 Aug 2001 & SPOT-1/10 m & $051 / 258$ & 29 Aug 2001 & ASTER/15 m & $124 / 511$ & 7 Sept 2001 \\
\hline 2002 & SPOT-2/20 m & $051 / 257$ & 28 Aug 2002 & Landsat-7/15 m & $195 / 029$ & 5 Oct 2002 & Landsat-7/15 m & $195 / 029$ & 5 Oct 2002 \\
\hline
\end{tabular}

Table 2. Remote-sensing data description 


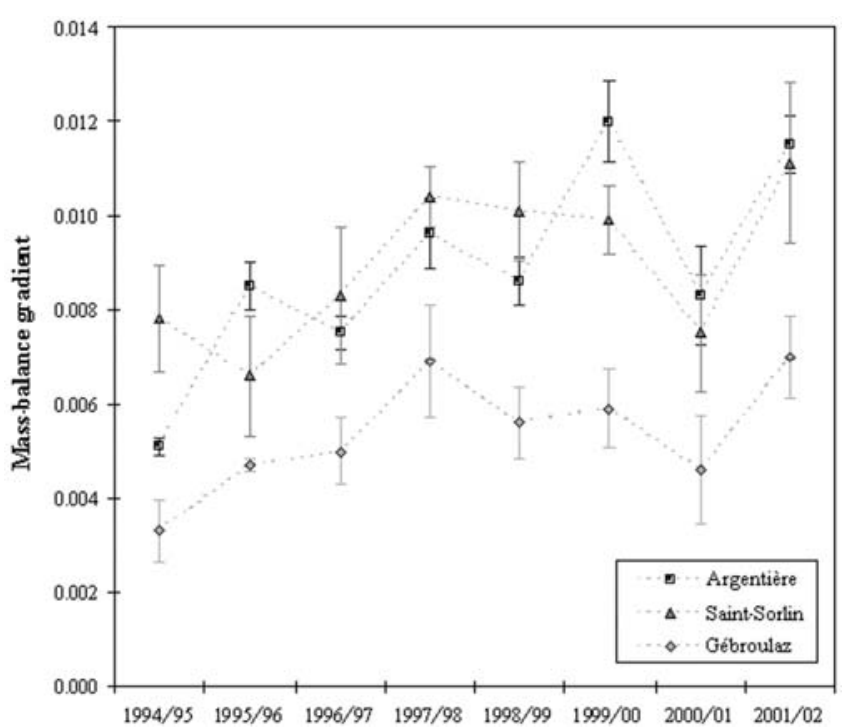

Fig. 5. Mass-balance gradient with altitude $\partial b / \partial z\left(\mathrm{~m}\right.$ w.e. $\left.\mathrm{m}^{-1}\right)$ close to the ELA (1994-2002). These data were obtained from field measurements. The uncertainty bars represent the standard error of the mass-balance gradient calculation obtained from the linear regression of the mass balance with stake altitude.

sensed ELAs using the procedure described above. For each glacier, the values obtained were compared with the mass balances calculated on the basis of field data measured from selected stakes located in a zone across the $\operatorname{ELA}_{\text {eq }}(2706 \mathrm{~m}$ for Glacier d'Argentière, $2829 \mathrm{~m}$ for Glacier de Saint-Sorlin and $2947 \mathrm{~m}$ for Glacier de Gébroulaz). Note that if ELA $\mathrm{eq}_{\mathrm{eq}}$ is computed with field ELAs, the values obtained are $2750 \mathrm{~m}$ for Glacier d'Argentière, $2865 \mathrm{~m}$ for Glacier de Saint-Sorlin and $2979 \mathrm{~m}$ for Glacier de Gébroulaz (see Fig. 4). Finally, for each glacier, we compared the cumulative mass balance obtained from remotely sensed data with the cumulative glacier-wide mass balance obtained from the whole stake network and photogrammetric measurements (see section 2).

\section{RESULTS AND DISCUSSION}

\subsection{Validation of the method}

Figure 6 shows an excellent correlation between the two series of ELA results $\left(r^{2}>0.89, \rho<0.01\right)$ and demonstrates that satellite images can be used to determine the ELA accurately.

Figure 7 shows good correlation between the series for yearly mass balance computed and measured at the remotely determined ELAs with $r^{2}>0.90 \quad(\rho<0.01)$. The average difference between the series for each glacier is low, between 0.24 and $0.51 \mathrm{~m}$ w.e. depending on the glacier. Nevertheless some years present differences of as much as $0.97 \mathrm{~m}$ w.e. (Glacier d'Argentière 1997/98 and 2001/02). These are mainly due to the recording dates of the satellite images and to the choice of $\partial b / \partial z$. The two dates should be as close as possible, but this can be difficult if, for instance, cloud cover or recent snowfall hides the snowline on the glacier at the end of the ablation season. Fortunately, the increase in the number of sensor-bearing satellites over recent years means images are now available over shorter intervals, which should make it easier to find usable images recorded at dates closer to the end of the hydrological year. In addition, if no

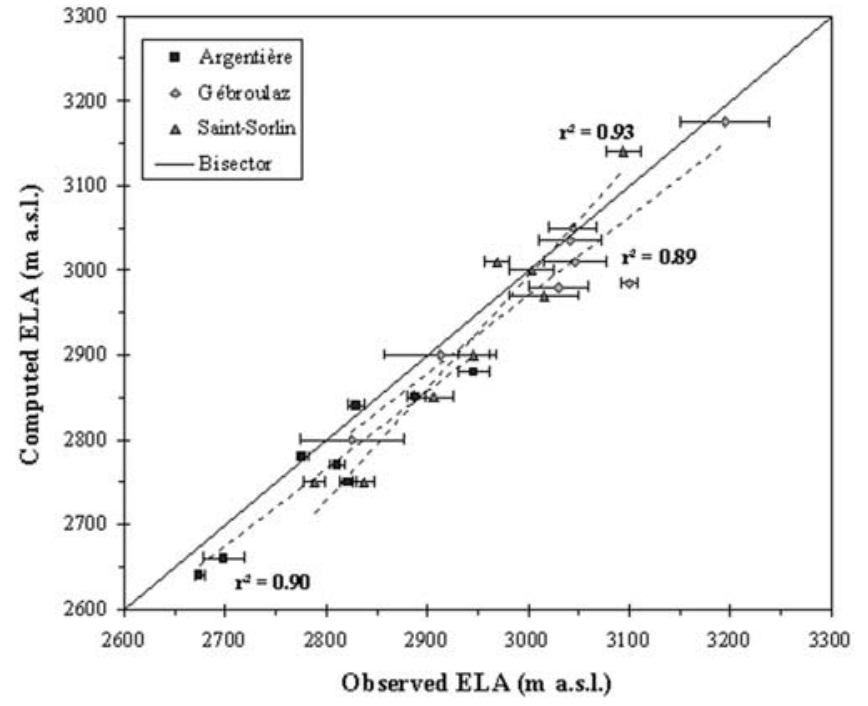

Fig. 6. Computed ELA obtained from remote sensing vs ELA observed from field measurements. Confidence intervals on the observed ELA are similar to those reported in Figure 4. Confidence intervals on the computed ELA depend on the pixel size of the images used $(<30 \mathrm{~m}$ in this study) and on the glacier slope across the ELA $(<20 \%$ for the three glaciers). They do not exceed $6 \mathrm{~m}$, and so are not shown.

optical image is available, it is possible to work with synthetic aperture radar (SAR) images. Geometrical processing of such images remains complex for mountainous areas but has proved successful in several studies (Adam and others, 1997; Engeset and Ødegard, 1999).

Figure 8 shows good correspondence between the series of cumulative mass balance obtained from remote-sensing and ground data. This indicates that the data obtained by remote sensing are representative of the glacier-wide mass balance. Note that both cumulative balances (remotesensing and field measurements) over the whole period are necessarily identical due to the method used (see Equations (1) and (2)). With this method, we determine the annual variation of the mass balance but do not attempt to assess the total volume variation over the period.

\subsection{Satellite data and DEM quality}

The accuracy of ELA determination from satellite images depends on the pixel size of the images used and the grid size of the DEM. Given the variation in the altitude of the equilibrium line from one side of the glacier to the other, even the average altitude for the central part of the glacier is difficult to determine to within $1 \mathrm{~m}$ (even with direct field measurements). An uncertainty of $10 \mathrm{~m}$ can be considered acceptable.

Uncertainties in the calculation of the ELA are reflected in the mass-balance calculation. Given a pixel size of $10 \mathrm{~m}$, a mass-balance gradient close to the ELA of $0.78 \mathrm{~m}(100 \mathrm{~m})^{-1}$ and a slope in the vicinity of the ELA of $<20 \%$ (respectively $8 \%, 14 \%$ and $17 \%$ on Argentière, Saint-Sorlin and Gébroulaz glaciers), the mass balance is calculated by the method using remotely sensed data with a maximum uncertainty of about \pm 0.016 m w.e.

A DEM with a grid size of $10 \mathrm{~m}$ appears to be appropriate, especially considering that for the 1970-2000 period the pixel size of the satellite images is generally $>10 \mathrm{~m}$. In 

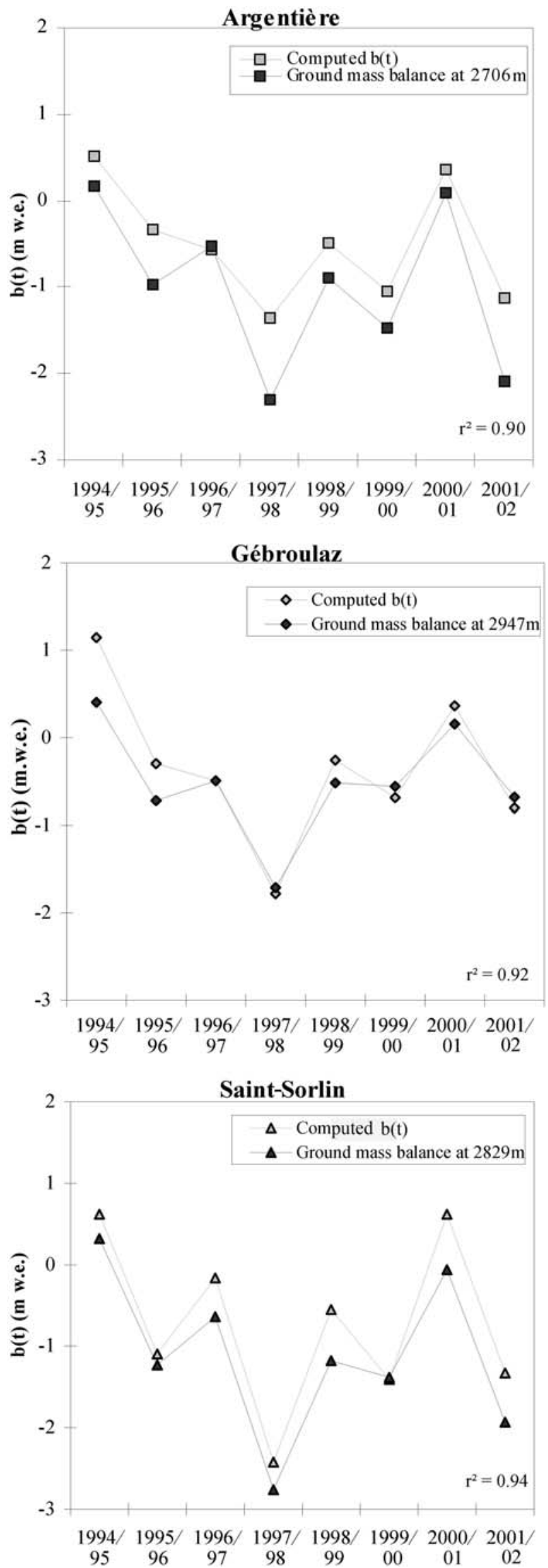

Fig. 7. Surface mass balance in the area of the equilibrium line from remote sensing (computed $b(t)$ ) and from field measurements (ground mass balance) for the three glaciers, 1994-2002. These mass-balance data have been determined at an ELA corresponding to the steady state of the glacier (see text).
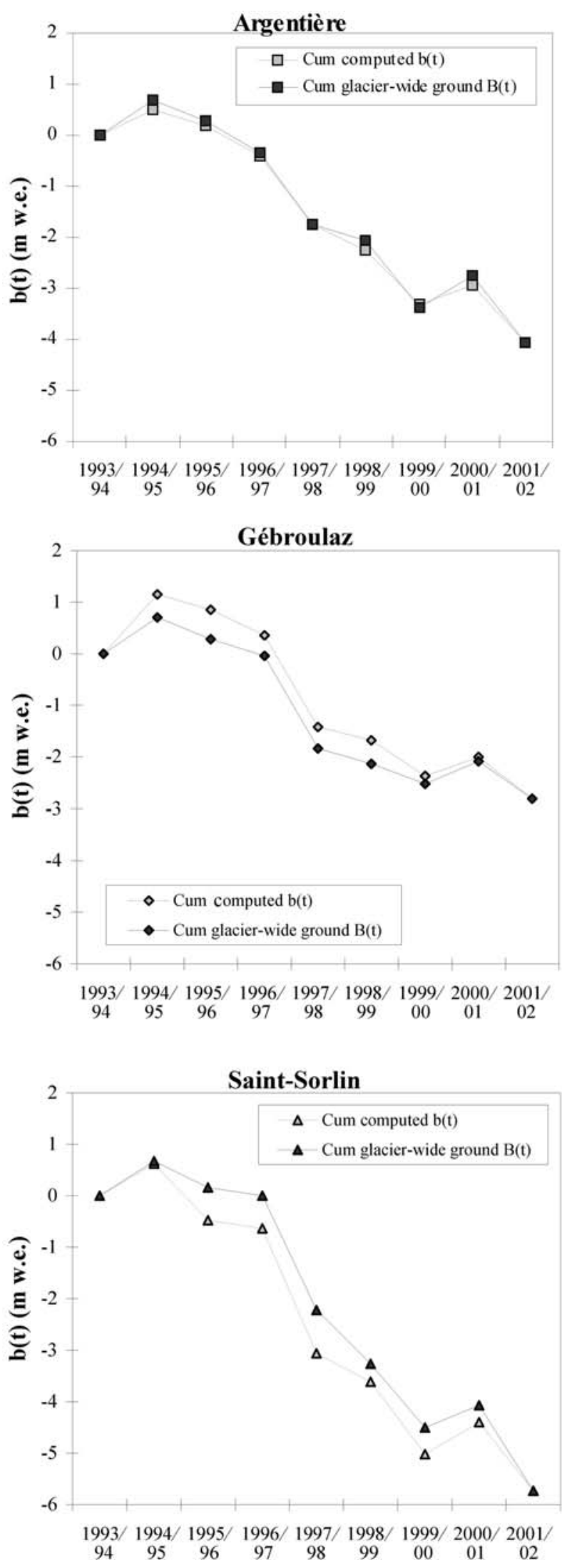

Fig. 8. Cumulative mass balance from remote sensing (Cum computed $b(t))$ and from field measurements (Cum glacier-wide ground $B(t))$ for the three glaciers, 1994-2002. 
addition, an old DEM can be used for this period given that the 1950-2000 glacier thickness variation at the ELA level is $<10 \mathrm{~m}$ (Vincent and others, 2000).

\subsection{Ablation correction using meteorological data}

It is possible to adjust the results obtained from remotely sensed data on the basis of meteorological data recorded at a station close to the study area. An empirical relation exists between glacier mass balance, temperature and precipitation, and a simple model of the 'positive degree-day' type can be used to determine the missing ablation (if the image used is recorded before the end of the hydrological year) and thus to improve the results (Vincent and Vallon, 1997; Vincent, 2002). In the context of this study, we carried out tests with the data of Lyon-Bron meteorological station $(80 \mathrm{~km}$ west of the Alps). The ablation corrections did not significantly modify the differences between the two series: for the 1994-2002 period the correlation coefficient only improves from 0.92 to 0.94 . For the period taken into account in this study, the recording date of the satellite images and the dates of field measurements are in good agreement in most cases, so the significance of the correction is not sufficient to justify its use here.

\subsection{Choice of $\partial b / \partial z$ across the equilibrium line}

$\partial b / \partial z$ across the equilibrium line represents the transfer parameter to transform an ELA variation into a mass-balance fluctuation (Equations (1) and (2)). Its value therefore influences the results. Figure 5 shows its spatial and temporal variation over the 1994-2002 period. In 1965, Lliboutry proposed a value of $0.6 \mathrm{~m}$ w.e. $(100 \mathrm{~m})^{-1}$ for the Alps; for the period under consideration in this study, field measurements on the three glaciers gave an average value of $0.78 \mathrm{~m}$ w.e. $(100 \mathrm{~m})^{-1}$ with high disparities $(0.33-$ $1.2 \mathrm{~m}\left(100 \mathrm{~m}^{-1}\right)$. Moreover, Figure 5 shows that the mean $\partial b / \partial z$ on Glacier de Gébroulaz is systematically lower $\left(0.54 \mathrm{~m}\right.$ w.e. $\left.(100 \mathrm{~m})^{-1}\right)$ than those on Glacier d'Argentière $\left(0.89 \mathrm{~m}\right.$ w.e. $\left.(100 \mathrm{~m})^{-1}\right)$ and Glacier de Saint-Sorlin $\left(0.9 \mathrm{mw}\right.$ w.e. $\left.(100 \mathrm{~m})^{-1}\right)$. These differences exceed the $95 \%$ confidence limits and are therefore significant. How can they be explained?

The mass-balance gradient differs strongly from one region to another. It varies according to regional climatic conditions and particularly accumulation amounts and ablation season length (Kuhn, 1984). For a homogeneous area, it is also sensitive to exposure, slope and shadowing (Oerlemans and Hoogendoorn, 1989). The geometry of the three glaciers is not very different (northern exposure) and not sufficient to explain the $\partial b / \partial z$ differences observed between these glaciers. On the other hand, detailed analysis of winter and summer balances on these three glaciers shows that winter accumulation on Glacier de Gébroulaz is approximately $20-50 \%$ lower than on the other glaciers (Vincent, 2002). Thus, annual mass balances measured at an equivalent altitude are lower on Glacier de Gébroulaz. This explains the higher ELA and the lower mass-balance gradient (Kuhn, 1984).

To quantify the importance of the chosen $\partial b / \partial z$ in the mass-balance calculation, we have applied our method to each glacier with its specific $\partial b / \partial z$. In comparison with the results presented here and computed with an average $\partial b / \partial z$ identical for the three glaciers (Figs 7 and 8 ), the choice of the specific $\partial b / \partial z$ of each glacier does not improve the correlation between field and remote-sensing measurements $\left(r^{2}>0.90\right)$. Considering the differences in absolute terms, the results are still not significantly improved: the average difference between remote-sensing and field mass-balance values rises from $0.24 \mathrm{~m}$ w.e. to $0.27 \mathrm{~m}$ w.e. for Glacier de Gébroulaz, and decreases from $0.51 \mathrm{~m}$ w.e. to $0.45 \mathrm{~m}$ w.e. for Glacier d'Argentière and from $0.40 \mathrm{~m}$ w.e. to $0.36 \mathrm{~m}$ w.e. for Glacier de Saint-Sorlin.

Thus, the choice of an average mass-balance gradient in the vicinity of the ELA, for a given period and climatic region, appears to be appropriate in the light of our results. This is important for the use of this method on glaciers where no direct field measurements are available and consequently where the specific mass-balance gradient across the ELA is unknown.

\subsection{Is the mass balance at the ELA representative of the glacier-wide mass balance?}

The position of the equilibrium line determined from remote-sensing data, and a known mass-balance gradient are theoretically sufficient to compute the glacier mass balance. However, such a calculation would be subject to high uncertainties. The ELA varies strongly with exposure, and the mass-balance gradient is not known over the whole glacier. As explained in section 3, our method is to calculate the ELA variation on a limited part of the glacier, deduce a mass-balance fluctuation from it and extrapolate this massbalance fluctuation to the whole glacier. Of course, the mass-balance variation is not the same throughout the glacier (Vallon and others, 1998), but our method (Fig. 4) and the work of other authors (Herren and others, 2002) show that the mass-balance variation observed across the ELA is representative of the glacier-wide mass-balance variation. For instance, over the 1994-2002 period, the mean differences are $<0.3 \mathrm{~m}$ w.e. for the three glaciers considered here. Data obtained over longer periods ( $>40$ years) on Swiss glaciers, in particular Griesgletscher and Silvrettagletscher, show similar values (Herren and others, 2002).

Nevertheless, these mass-balance variations do not provide the net balances. To calculate the net balances, we must use an independent method capable of determining the total volume lost by the glacier over the whole period, i.e. its cumulative mass balance. In this study, these data were obtained from field measurements, but they can also be computed by photogrammetry or with satellite images (Berthier and others, 2004). The cumulative mass balance of the glacier then made it possible to calculate the theoretical ELA $\mathrm{eq}_{\mathrm{eq}}$ corresponding to a steady state of the glacier over the period concerned, and to take into account the surface area variation of the glaciers with time. This choice is arbitrary but offers the advantage of providing mass-balance values directly comparable with observed specific mass balances on the glaciers. As a reference, we could also have chosen the arithmetic average ELA measured by remote sensing over the whole period. In fact, this choice does not change the correlation between the reconstructed mass balance using remote-sensing data and the observed mass balance obtained with field measurements (Rabatel and others, 2002).

\section{CONCLUSIONS}

This study shows that remote sensing may be regarded as an adequate tool to reconstruct annual mass-balance series on 
glaciers where few or no direct field measurements are available. It can also be used to complete incomplete or interrupted series of field measurements. For glacier monitoring, photogrammetry and remote sensing appear to be complementary, i.e. photogrammetry can be used to calculate the total volume variation of a glacier over a given period, and remote sensing to reconstruct the annual massbalance variation over this period.

Over the whole 1994-2002 period, results provided by our method of mass-balance calculation using optical remote-sensing data are satisfactory. Differences between the results obtained from remote-sensing data and field measurements remain on the whole quite small (on average, $0.24-0.51 \mathrm{~m}$ w.e. for the three glaciers). Thus, this method provides an effective way to reconstruct mass-balance series on the scale of a mountain range of moderate size, firstly because satellite images cover large areas and secondly because of the relative simplicity of the method.

However, it must be kept in mind that the results mainly depend on the recording date of the images which must correspond to the end of the hydrological year, and meteorological conditions may limit the use of optical data due to cloud or snow cover. In such a case, it is also possible to use SAR images. The main interest of radar sensors is to eliminate these restrictions related to meteorological conditions. However, improvements in the image-processing procedure are still necessary to reach the quality of the results obtained with optical images.

\section{ACKNOWLEDGEMENTS}

We thank the space agencies that provided satellite image data: the CNES (Centre National d'Etudes Spatiales, France)ISIS (Incentive for the Scientific use of Images from the SPOT system)/SPOT image contract Nos. 0103-157 and 0412-725, and the GLIMS program (ASTER, Landsat Enhanced Thematic Mapper data). We thank T. Scambos (scientific editor) and M. Truffer for helpful comments and suggestions. We thank L. Reynaud and all those who collected data for field measurements on the glaciers. This study was funded by the French Glacier Observatory Service (Observatoire des Sciences de I'Univers de Grenoble-Institut National des Sciences de I'Univers); and the Action Concertée Incitative (ACl) 'Observation de la Terre' (French Ministry of Research).

\section{REFERENCES}

Adam, S., A. Pietroniro and M.M. Brugman. 1997. Glacier snow line mapping using ERS-1 SAR imagery. Remote Sens. Environ., 61(1), 46-54.

Berthier, E., Y. Arnaud, D. Baratoux, C. Vincent and F. Rémy. 2004. Recent rapid thinning of the Mer de Glace glacier derived from satellite optical images. Geophys. Res. Lett., 31, L17401. (10.1029/2004GL020706.)

Bindschadler, R. 1998. Monitoring ice sheet behavior from space. Rev. Geophys., 36(1), 79-104.

Braithwaite, R.J. 1984. Can the mass balance of a glacier be estimated from its equilibrium-line altitude? J. Glaciol., 30(106), 364-368.

Braithwaite, R.J. and Y. Zhang. 1999. Relationships between interannual variability of glacier mass balance and climate. J. Glaciol., 45(151), 456-462.

De Ruyter de Wildt, M.S. and J. Oerlemans. 2003. Satellite retrieval of mass balance: comparing SAR images with albedo images and in situ mass balance observations. J. Glaciol., 49(166), 437-448.

Dedieu, J.P. and L. Reynaud. 1990. Télédétection appliquée au suivi des glaciers des Alpes françaises (années 1986, 1987 et 1988). La Houille Blanche, 5, 355-358.

Engeset, R.V. and R.S. Ødegård. 1999. Comparison of annual changes in winter ERS-1 SAR images and glacier mass balance of Slakbreen, Svalbard. Int. J. Remote Sensing, 20(2), 259-271.

Herren, E.R., M. Hoelzle, M. Maisch and A. Bauder. 2002. The Swiss glaciers, 1999/2000 and 2000/2001. Zürich, Swiss Academy of Sciences. Glaciological Commission; Federal Institute of Technology. (Glaciological Report No. 121/122.)

Houghton, J.T. and 7 others, eds. 2001. Climate change 2001: the scientific basis. Contribution of Working Group I to the Third Assessment Report of the Intergovernmental Panel on Climate Change. Cambridge, etc., Cambridge University Press.

Hubbard, A. and 6 others. 2000. Glacier mass-balance determination by remote sensing and high-resolution modelling. J. Glaciol., 46(154), 491-498.

Kääb, A., F. Paul, M. Maisch, M. Hoelzle and W. Haeberli. 2002. The new remote-sensing-derived Swiss glacier inventory: II. First results. Ann. Glaciol., 34, 362-366.

Kaser, G. 2001. Glacier-climate interaction at low latitudes. J. Glaciol., 47(157), 195-204.

König, M., J.G. Winther and E. Isaksson. 2001. Measuring snow and glacier ice properties from satellite. Rev. Geophys., 39(1), 1-28.

Kuhn, M. 1984. Mass budget imbalances as criterion for a climatic classification of glaciers. Geogr. Ann., 66A(3), 229-238.

Kuhn, M. 1989. The response of the equilibrium line altitude to climatic fluctuations: theory and observations. In Oerlemans, J., ed. Glacier fluctuations and climatic change. Dordrecht, etc., Kluwer Academic Publishers, 407-417.

Leonard, K.C. and A.G. Fountain. 2003. Map-based methods for estimating glacier equilibrium-line altitudes. J. Glaciol., 49(166), 329-336.

Lliboutry, L. 1965. Traité de glaciology. Tome II: Glaciers, variations du climat, sols gelés edition. Paris, Masson et Cie.

Martin, S. 1974. Correlation bilans de masse annuels-facteurs météorologiques dans les Grandes Rousses. Z. Gletscherkd. Glazialgeol., 10, 89-100.

Massom, R. 1995. Satellite remote sensing of polar snow and ice: present status and future directions. Polar Record, 31(177), 99-114.

Meier, M.F. 1979. Remote sensing of snow and ice. Paris, Unesco/ International Association of Hydrological Sciences. (Technical Papers in Hydrology 19.)

Oerlemans, J. and N.C. Hoogendoorn. 1989. Mass-balance gradients and climatic change. J. Glaciol., 35(121), 399-405.

Oerlemans, J. and B.K. Reichert. 2000. Relating glacier mass balance to meteorological data by using a seasonal sensitivity characteristic. J. Glaciol., 46(152), 1-6.

Oerlemans, J. and 10 others. 1998. Modelling the response of glaciers to climate warming. Climate Dyn., 14(4), 267-274.

Østrem, G. 1975. ERTS data in glaciology - an effort to monitor glacier mass balance from satellite imagery. J. Glaciol., 15(73), 403-415.

Paterson, W.S.B. 1994. The physics of glaciers. Third edition. Oxford, etc., Elsevier.

Paul, F., C. Huggel and A. Kääb. 2004. Combining satellite multispectral image data and a digital elevation model for mapping debris-covered glaciers. Remote Sens. Environ., 89, 510-518.

Rabatel, A., J.P. Dedieu and L. Reynaud. 2002. Reconstitution des fluctuations du bilan de masse du Glacier Blanc (Massif des Ecrins, France) par télédétection optique (imagerie Spot et Landsat). La Houille Blanche, 6/7, 64-71.

Raup, B.H., H.H. Kieffer, T.M. Hare and J.S. Kargel. 2000. Generation of data acquisition requests for the ASTER satellite instrument for monitoring a globally distributed target. IEEE Trans. Geosci. Remote Sens., 38(2), 1105-1112. 
Reynaud, L., M. Vallon and A. Letréguilly. 1986. Mass-balance measurements: problems and two new methods of determining variations. J. Glaciol., 32(112), 446-454.

Vallon, M., C. Vincent and L. Reynaud. 1998. Altitudinal gradient of mass-balance sensitivity to climatic change from 18 years of observations on glacier d'Argentière, France. J. Glaciol., 44(146), 93-96.

Vincent, C. 2002. Influence of climate change over the 20th century on four French glacier mass balances. J. Geophys. Res., 107(D19), 4375. (10.1029/2001JD000832.)
Vincent, C. and M. Vallon. 1997. Meteorological controls on glacier mass balance: empirical relations suggested by measurements on glacier de Sarennes, France. J. Glaciol., 43(143), 131-137.

Vincent, C., M. Vallon, L. Reynaud and E.L. Meur. 2000. Dynamic behaviour analysis of glacier de Saint Sorlin, France, from 40 years of observations, 1957-97. J. Glaciol., 46(154), 499-506. Vincent, C., G. Kappenberger, F. Valla, A. Bauder, M. Funk and E. Le Meur. 2004. Ice ablation as evidence of climate change in the Alps over the 20th century. J. Geophys. Res., 109(D10), D10104. (10.1029/2003JD003857.)

MS received 18 February 2005 and accepted in revised form 23 August 2005 